Bangladesh Journal of Bioethics 2019; 10 (3) 14-18

\title{
Youth Action Against Moral Deterioration
}

\author{
Mehedi Mala Mitu \\ Master Student of Clinical Pharmacy and Pharmacology \\ North South University, Dhaka \\ Email: mitumala043@gmail.com
}

DOI: https://doi.org/10.3329/bioethics.v10i2.50653

\begin{abstract}
In Past, Chinese traveler Fa-hien ( $14^{\text {th }}$ century) to Ibn batuta $\left(14^{\text {th }}\right.$ century $)$ or from Nicola Kanti ( $15^{\text {th }}$ century) to Queen Elizabeth $\left(20^{\text {th }}\right.$ Century), every travelers and scholars are attracted by the charms and fame of Bangladesh. Ibn batuta described Bengal as "a hell full of bounties" and "wealthiest" land of the world". But now a day, along this progress anxiety has proportionately increased. In this present age, science and technology are the easily available to common people. The world has come to a handful but yet people are still not so happy. As if the demand is insatiable. So, anxiety, apathy, intolerance, fear and panic are increased. Morality is deemed declining. Why immorality among young increased is a concern? Mark Twain said, "Always do what is right, it will gratify half of mankind". What is right? a vantage point is needed to know. Our moral values which guide us and aids us in our conscious mobility in life. This article tries to find out the cause root of immorality among young generation and how to protect young generation from this moral deterioration.
\end{abstract}

Key words: youth, new generation, morality, moral deterioration

(Some part of this article presented at the 20 th Asian Bioethics Conference, 22-25 November 2019, Dhaka, Bangladesh).

Introduction: The word "mortality" came from a Latin word "Moralis" means "character, manner or proper behavior". According to the Merriam- Webster dictionary the definition of the word moral is "concerning or relating to what is right and wrong in human behavior". Morality is generally regarded as a standard or ideal criterion which is based on the social tradition, culture, religion etc. The literal meaning of the word "moral decay" is deterioration of the moral value like patience, generosity, courtesy etc.

Inspector general of Bangladesh police A.K.M. Shohidul haque said, according to psychologists Sigmund Freud's theory, three tendencies are innate in every human being- as for example id, ego and superego. The id satisfy certain basic needs, such as food, sex, power, etc. Under the influence of ego, a person can balance everything. Superego can bestow superhuman qualities of a person and a person can become an inhuman and he does not hesitate to commit any crime or heinous act with increase in id's influence. He does not even have the sense of laws, sins and guilt also transformed into a person of unscrupulous and perverted taste. In this type of superego is seen Bangladesh. Despite immediate legal action against a gang rape accused in Subarnachar, Bangladesh, a mother of six children was raped within three months of this legal action. 
Actually, good education, self-education and the practice of civility are needed to increase ego's influence by suppressing id. At the same time, it is essential to provide exemplary speedy punishment to the perpetrators of such perverted tastes through strict enforcement of law including socially boycott them. Therefore, this article This article has been written to find out the cause of deterioration among young generation and what are the action need to increase ego's influence by suppressing id.

Cause of Moral Deterioration: There are certain reasons behind the moral decay of a society, some notable reasons are discussed below:

Lack of proper education: Education is the backbone of a nation. The relationship between education and development of a nation is proportional. Education is the first guidance for the world humanity. Because only by acquiring knowledge, people can understand the difference between truth and falsehood, justice and injustice. But nowadays most of the education is certificate based. Students are falling behind in their moral education rather run after to pursuit a good result that leading to increasing in moral decay.

Drug availability: Intoxication seems to be in the vein of many youth in Bangladesh. The number of drug addicts were 1.7 million in 2001 and in 2019 it is 7.5 million. Drug addicts are involved in various crime to collect their money to buy drugs. Oishee, a drug addicted young girl killed her parents by sharp blade. is one of the most unprecedented immoral acts in Bangladesh.

Terror on campus: The campus is a sacred place where students will acquire knowledge.
But unfortunately, terrorism has been developed in the student's politics which disrupting the learning environment of the university and facing ordinary students suffering from insecurity. Terrorism on campus is becoming the foothold of moral deterioration. The youth must join in a healthy politics. Only an honest politician can remove corruption from the country. An honest political leader can motivate a hundred young people to defend their morals and values. Corruption can be eradicated from the society by relying on ethics.

The effect of unemployment: At present, per capita income of Bangladesh is about 1,909 US Dollars. Despite the increase in per capita income, Bangladesh has the highest unemployment rate among South Asian countries. This rate was doubled in the past 6 years. Poverty is increasing due to the impact of unemployment. Although the number of higher degrees is increased, but the number of qualified job opportunities for them is not increased. According to International Labor Organization (ILO), 56\% Bangladeshi involved in workforce feel that they are not paid a fair rate. So, some of them get involved in various types of immoral activities like bribery to fulfill their basic needs.

Internet access: Every part of the world there are $4 \mathrm{G}, 5 \mathrm{G}$. It takes a second to bring everything including pornography in front of eyes of young people of Bangladesh like other part of the world. Easy access and inappropriate use of internet is also responsible for moral deterioration. Some young people are fascinated by western culture and watch inappropriate subjects. As a result, number of rape case is increased than before. The number of rapes in 2001 was 622 . In 2019, for first 6 month it was 731 for women and 496 for children respectively. 
Age between 6-month-old girl to a 60-yearold lady seems to not be getting rid from rape. So, at present times, moral decadence is like an alarming disease to us.

Breaking down the Traditional system: There was a time when children used to greet elders and elders used to love children. The elders used to rule when someone in the family did wrong. But in the evolution of time, these are very rare nowadays. Urbanization is taking place by breaking down the traditional systems. The rule and discipline are being loosened specially in city system, causing of erosion of moral values.

Lack of religious education: Religion has a great impact on daily life of any human being. In Islam it is said that, "the teaching of morality is the greatest asset for the children". Not only in Islam but also in all religions, moral education has given the priority. Children learn good things of religion and refrain from bad things. Lack of religious education may be one of the causes of increase moral deterioration.

The intrusion of corruption: Currently, corruption seems rampage in our society. Corruption enter into education, food, medicine etc. What will the students learn from a corrupted teacher? One of the examples of moral decay in education is leaking of questions paper of exam. Some medical students are taught in "education and service". Therefore, some doctors only run after money. Because of less importance has been given on medical ethics education while they were student. So, there is a lack of moral value among them.

\section{Role of Youth Society in Preventing Moral}

Decay: Young society is the most important population of a country. They have endless vitality than children or older society. They are the present and future of Bangladesh. It is the youth who brings color to this aging world. It is the youth who gives hope to the hopeless, who brings changes to a society. Their efforts can lead a nation to thrive and live-in harmony. From generation to generation the youth have been the main shield to protect this country. From the language movement in 1952 to the liberation war in 1971 or from the chaotic situation in 1990 to the protest for safe road in 2018, the young society have kept the soil of the country tight.

But at present, because of the broken family, availability of drug, misuse of internet, some young generation is on the verge of collapse today. Some are creating gang culture in different places and getting involved in robbery only because of moral decay. They forget to practice moral values rather than give more importance to enjoyment and domination attitude. A book named youth and development says, "The descendant of the youth is due to the environmental reflection bad effects of science and technology, state's apathy and above all, family's indifference." This deviance of the youth is a threat to the country. Young people are the future doctors, engineers, pharmacists, ministers that means the main infrastructure of the country is in their hands. So, if they take morality as the standard of their ideology, it will then be the sustainable development for a country.

Young society is the state asset and they are the main driving force of a country. Only the youth can suppress the current anarchy in the country. Although we as human beings have reached the pinnacle of civilization and the pinnacle of humanity. But sadly, we have come down further in terms of human beings. 
Love and respect are almost become zero. When an animal is born, it's already an animal but when a human child is born, he needs to be a human with time by learning and transforming moral values. Moral education comes from the family. Children are given with moral education by family that raise them as the future leaders of our society. When a child comes out family boundary, society also has responsibilities to create morality among the children. It is possible to create values among the children by organizing various social awareness programs, discussion meetings and cultural programs.

\section{Action Against Moral Deterioration:}

Student Club: Generally, the university students are attached with many club activities. They can open a club with the need for moral education and values. The main purpose of this club should be educated morally to school children and college teenagers. College students need to pay special attention in this case because during this period of time teenagers are more prone to crime. Therefore, they can organize various seminars and rallies routinely. They can organize mobile library so that every age of people can borrow books from them as books keep people away from immoral acts.

Moral Education in Institution: Educational institutions are the best place to create morality inside a person. When a child leaves the family boundary, they enter educational institutions first. But it is a pity that at present, only science, technical, professional subjects are given more emphasis rather moral education. As a result, nation is getting doctors, engineers but there is no ethics in them. So, some doctors become butchers and some engineers become corrupted. So moral education is essential in institution. University authority should come forward to show interest in incorporating morality in the syllabus.

Avoid internet addiction: Young society must always choose the true path. They should use internet accurately. Always accept things those are good and they should not spend too much time on social media rather concentrate on reading various types of constructive literature and books in internet. Young generation can make small messages on moral values and its importance and send it to others. However, they can make short stories or drama to raise awareness about moral decay by posting it on social media.

Create employment: Unemployment is the cause of moral decay for most young men and women. They are suffering from depression as they are not getting jobs even after getting higher education. Out of that frustration, they are engaging in various immoral activities. So, they have to build themselves as successful entrepreneurs from their respective places and not just rely on the administration. Those who are successful entrepreneurs can make people aware by organizing seminars or discussion meetings. This will reduce unemployment as well as moral decaying.

Sports: The youth has to be playful. They have to involve themselves in all kinds of sports like cricket, football, volleyball, badminton. Because playing keeps both mind and body fresh. For entertainment they should not rely on smartphone rather they can play various types of sports.

Religion: The essence of every religion is discipline and values. Religion is one of the tool for creating moral education. By 
practicing religion properly, the youth will be able to protect them from moral decaying.

Conclusion: Today's young woman is the bearer of the next generation. Napoleon said, "Give me an educated mother and I will give you an educated nation". So, it is very important for young woman to have moral education. A child who learns morality from an early age cannot do anything bad thing in the future. It is not possible to prevent from this moral decay overnight. This requires long-term planning. Who doesn't want a country where there will be no violence, no food adulteration, have security for girls, no corruption, no fear of death on the streets?

Acknowledgement: I would like to thank Prof Shamima Lasker, Professor \& Head of Anatomy, Shahabuddin Medical College for her feedback on various versions of this paper. I express my gratitude to her for giving me opportunity to publish this article. I also thanks to Dr Sharmin Islam for encouraging me to write this article.

\section{References:}

1. Angelo Valenti, Always do what is right. It will gratify half of mankind and astound the other. - Mark Twain. 2018 .

https://www.linkedin.com/pulse/always-do-whatright-gratify-half-mankind-astound-other-valenti (Accessed Nov 2019)

2.Definition of moral. https://www.merriamwebster.com/dictionary/moral (Accessed Nov 2019)

3.Drug addiction Bangladesh. Dhaka Tribune, $27^{\text {th }}$ February, 2019

4.Inspector general of Bangladesh police A.K.M. Shohidul haque . Daily News Kaler Kantho, 16 April, 2019, Dhaka, Bangladesh.

5.Per capita income of Banglades. Daily News Prothom Alo, 19 ${ }^{\text {th }}$ March, 2019, Dhaka, Bangladesh. 6.Rape cases in Bangladesh. Bangladesh. Daily News Protidin, $20^{\text {th }}$ April, 2019
Who doesn't want such a country? It is true that the country became independent in 1971, but in order to ensure the true independence of all citizens, the youth must come forward to resort morality. Youth have to stand by the side of this endangered humanity and all the moral decaying of the society with the strong wind of their youth. How fire purifies gold from impurities, moral values do the same to us. Moral values are as important as the air we breathe, moral values are as important as the water we drink. Moral values make us human. Moral values are what makes life worth-living for ourselves and for others. Moral education may increase ego's influence by suppressing id.

7.Shamima Lasker and Arif Hossain. Teaching of bioethics in medical schools in Bangladesh. Eubios Journal of Asian and International Bioethics 2008; 18(6): 180-81.

8. Shamima Lasker and Arif Hossain. Introduction of bioethics and its necessity in Bangladesh

Bangladesh Journal of Bioethics 2010; 1(1):2.

9.Utah state board of education career and technical education. Causes of crime. 2016. Https://www.uen.org/lawenfstudent/downloads/le ch $\underline{3 . p d f}$ (Accessed October 2019)

Authors' contribution: Author conceived the idea of the paper. She involved in the literature search, manuscript writing and revision.

Conflict of interest: None to disclose 